\title{
THE EFFECTIVENESS OF HUGGING IN REDUCING DEPRESSION AND THE FEELING OF POWERLESSNESS IN THE AFFECTED ADOLESCENTS
}

\author{
Muhammad Ali Adriansyah, Sugandi, Lisda Sofia, Netty Dian Prastika \\ Universitas Mulawarman, Samarinda, East Kalimantan
}

\begin{abstract}
Background: Hug therapy, or hugging therapy, is using hugs to provide emotional comfort and healing. Recent studies have found that the simple act of hugging can help people who suffer from stress, depression, anxiety, and loneliness. The benefits of hugging come from the power of touch. The reason for this is oxytocin, a hormone that brain naturally releases into the system whenever the affected engages in hugging, cuddling, or physical intimacy. The study proved that oxytocin helped people overcome social rejection. One of the studies on the effects of this "cuddle hormone" was published in the medical journal Psychoneuroendocrinology. Little is known on the effect of hugging on depression and feeling of powerlessness in an Indonesian population. This study aimed to examine the effectiveness of hugging in reducing depression and the feeling of powerlessness in the affected adolescents.
\end{abstract}

Subjects and Method: This was a randomized control trial involving 20 adolescents affected with depression and feeling of powerlessness. This sample was taken from out-patients visiting Atmahusada Mahakam Mental Hospital, Samarinda, East Kalimantan. As many as 10 subjects in the experimental group received hug therapy, and 10 subjects in the control group received no hug therapy. The dependent variables were depression and feeling of powerlessness. The independent variable was hug therapy. Depression was measured by Beck depression inventory (BDI). Feeling of powerlessness was measured by Beck's Hopelessness Scale (BHS). The difference in the proportion of the affected subjects after the intervention was analyzed by Chi square.

Results: After the intervention, the proportion of the depressed subjects in the hug therapy group were $7(70 \%)$ and in the control group were 9 (90\%) with $\mathrm{p}=0.265$. Likewise, after the intervention, the proportion of subjects with the feeling of powerlessness in the hug therapy group were $8(80 \%)$ and in the control group were 9 (90\%) with $\mathrm{p}=0.531$.

Conclusion: Hug therapy alone is not effective to reduce depression and feeling of powerlessness in the affected adolescents.

Keywords: depression, powerlessness, hug therapy, adolescents

\section{Correspondence:}

Muhammad Ali Adriansyah. Universitas Mulawarman, Samarinda, East Kalimantan. Email: ali.adriansyah@gmail.com. Mobile: 081335350368.

Mid-International Conference on Public Health, Best Western Premier Hotel, Solo, Indonesia, 18-19 April 2018 | 258 https://doi.org/10.26911/mid.icph.2018.05.20 